\begin{tabular}{|c|c|c|c|}
\hline & 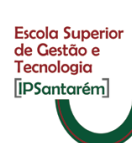 & JKU & $\begin{array}{l}\text { ISSN 2029-7564 (online) } \\
\text { SOCIALINES TECHNOLOGIJOS } \\
\text { SOCIAL TECHNOLOGIES } \\
2014,4(1) \text {, p. } 192-204\end{array}$ \\
\hline
\end{tabular}

\title{
KLASTERIŲ VEIKLA LIETUVOJE: IŠŠŨKIAI IR GALIMYBIŲ PAIEŠKA
}

\author{
Aelita Skaržauskienè \\ Mykolo Romerio universitetas, Lietuva, aelita@mruni.eu \\ Laura Gudelytè \\ Mykolo Romerio universitetas, Lietuva, 1.gudelyte@mruni.eu \\ Asta Lančinskienè \\ Mykolo Romerio universitetas, Lietuva, asta.lancinskiene@gmail.com \\ doi:10.13165/ST-14-4-1-13
}

\section{Santrauka}

Tikslas - analizuoti ir apibendrinti inovatyviu verslo imoniu klasteriu veiklos Lietuvoje problemas bei pateikti siūlymus, kaip bütų galima tobulinti situacija, ir nustatyti pagrindinius ju veiklos rizikos šaltinius.

Metodologija - bendroji mokslinès literatūros apžvalga, kurioje pateikiamos verslo klasteriu veiklos efektyvumo ir veiksnių, darančiu neigiama įtaka ju veiklai, analizes metodikos, atvejo analize.

Rezultatai - nustatyta verslo klasterių rizikos struktūra, problemos Lietuvoje ir tobulintini dalykai.

Tyrimo ribotumas - tyrimo ribotuma lemia kiekybiniu duomenu trūkumas ir informacijos konfidencialumas. Dèl šios priežasties kyla sunkumų sukurti adekvačius dinaminius veiklos efektyvumo vertinimo modelius.

Praktinè reikšmè - inovacijų plètra ir viešojoje erdvejje, ir siauresnejje akademinèje erdvèje pateikiama gana vienpusiškai, kaip pažangos rodiklis, tačiau Lietuvoje mažai 
diskusiju, ar klasteris tikrai yra optimali forma siekiant sukurti sąlygas verslo inovacijoms. Taip pat iki šiol nepakankamai analizuota rizika, susijusi su inovaciju kūrimu ir klasterizacija, nors tai yra vienas pagrindiniu rizikos kapitalo fondu finansavimo objektas. Šiuo straipsniu siekiama nustatyti verslo klasteriams büdingas rizikos savybes ir struktūrą.

Originalumas / vertingumas - išskiriamos pagrindinès klasteriu veiklos Lietuvoje efektyvumo ir rizikos vertinimo problemos, apibrëžiama klasteriu veiklos rizikos struktūra.

Raktažodžiai: klasteris, klasterizacija, rizikos struktūra.

Tyrimo tipas: literatūros apžvalga, bendroji apžvalga.

\section{Ivadas}

Verslo įmonių klasteriai ir klasterizacija kartu su rizikos kapitalo fondais kaip naujų verslo nišų paieškos ir konkurencingumo didinimo formos sulaukia vis didesnio verslo ir akademinès visuomenès dèmesio ne tik užsienio šalyse, bet ir Lietuvoje. Viena iš svarbiausių priežasčių, skatinančių šių procesų augimą, yra siekis paspartinti verslo įmonių vystymąsi, inovacijų plètrą ir šalies konkurencingumą bei gerovę. Kitas veiksnys, kuris skatina domejjimąsi klasteriais, yra globalizacijos ittaka konkurencijos prigimčiai ir intensyvumui.

Mokslineje literatūroje yra nusistovėjęs ne vienas klasterių ir klasterizacijos apibrèžimas. Verslo įmonių klasteris suprantamas kaip geografinè koncentracija tarpusavyje susijusių įmonių, specializuotų tiekejų, paslaugų teikejų bei asocijuotų institucijų (pvz., universitetų, standartizavimo agentūrų, profesinių sąjungų), kurie tarpusavyje ir konkuruoja, ir kooperuojasi bendriems projektams (Porter, 1998). Kamarulzaman, Mariati, analizuodami klasterių sąvoką, pabrèžia reikšmingą geografinę subjektų koncentraciją, lemiančią subjektų betarpiškumą bei oficialią ir neoficialią jų sąveiką, aglomeracijos ekonomiją, ir dideli socialinị kapitalą, kurie skatina sklaidą ir daro reikšmingą ittaką regiono ar visos šalies ekonomikai (Kamarulzaman, Mariati, 2008). Galima daryti prielaidą, kad klasterizacijos procesai užtikrina darnesnę sektoriaus plètrą, naują veiklos kokybę derinant gebėjimą konkuruoti mažesnèmis sąnaudomis, produkto kokybe ir novatoriškumu.

Imonių klasteriai skatina šalies ekonomikos augimą bei darbo jẻgos užimtumą, taip pat, nors ir atitraukdami žmogiškąji kapitalą nuo ịprastos veiklos, pritraukia naujas technologijas, kvalifikuotus darbuotojus bei investicijas i mokslinius tyrimus. Be to, reikia atkreipti demesị $\mathfrak{i}$ faktą, kad verslo įmonių klasterių steigimas ir veikla gali būti pagrịsti ne vien tik siekiant sukurti bei komercializuoti inovaciją, tačiau ir siekiant masto ekonomijos efekto. Vertinant sektoriaus klasterizacijos procesus turi būti atsižvelgiama ị sektoriaus kultūrą, konkurencines galimybes bei darnią regiono plètrą. Siekiant užtikrinti aukštą kurio nors sektoriaus konkurencingumo lygi svarbus subalansuotas įmonių ar jų grupių tarpusavio bendradarbiavimas, kuris klasterio nariams suteikia galimybę mažinti sąnaudas igyjant naujas žinias bei technologijas, sukuria 
daugiau mokymosi galimybių, leidžia tolygiau paskirstyti riziką, mokslinių tyrimų ir taikomosios veiklos išlaidas. Sklandus bendradarbiavimas klasteryje taip pat padeda sumažinti naujų produktų ar procesų ịvedimo ị rinką trukmę (Jucevičius ir kt., 2012), kuri yra viena iš svarbiausių charakteristikų siekiant išorinio finansavimo inovaciju komercializavimui. Be to, pabrežiama tokia klasterių teikiama nauda jų dalyviams:

1) veikdamos bendrai klasterio įmonès turi daugiau galimybių didinti produktyvumą nei veikdamos atskirai;

2) klasterizacija padeda didinti ne vienos įmonès, bet viso sektoriaus konkurencingumą;

3) kartu su antreprenerystès suvokimu sukuriamos patrauklesnès sąlygos inovacijoms.

Globalejančios ekonomikos sąlygomis siekiant skatinti inovacijų atsiradimą ir jų diegimą šalyje, klasteriai ir atskirų sektoriaus įmonių klasterizacija suteikia papildomų galimybių skatinti konkurencingumą, inovacijų plètrą bei skatinti ūkio augimą.

Klasterių valdymą bei jų kūrimuisi perspektyvias sritis Lietuvoje nagrinejjo Jucevičius, kurio darbuose nuosekliai išanalizuoti klasteriai, jų tipai, kūrimosi procesai bei jų valdymas, taip pat aptartos klasterių kūrimuisi perspektyvios sritys (Jucevičius, 2008, 2009a, 2009b). Be to, šiuose darbuose yra išanalizuoti klasterių atsiradimui ittaką darantys veiksniai, klasterio sąvoka ir jo savybès, teikiama nauda bei klasterio santykis su kitomis organizacijų ryšiu formomis, nagrinejjama klasterizacijos politika, t. y. klasterizacijos procesų itaka šalies ūkio konkurencingumui, statistinè klasterizacijos analizè, klasterių politikos principai, gairès ir kt. Tačiau palyginti nedaug mokslinių darbų, ypač Lietuvoje, skirta išsamesnei klasterių veiklos efektyvumo ir jų rizikos vertinimo analizei, pagrịstai kiekybiniais metodais. Stalgiené savo darbe nustate išorines kliūtis klasterių kūrimui (Stalgienė, 2010), labiau juos siedama su rinkos netobulumais ir netinkamais valdymo instituciju ir kitais politiniais sprendimais.

Šiuo straipsniu siekiama apžvelgti tipines klasterių veiklos problemas, identifikuoti pagrindinius jų rizikos šaltinius ir aptarti galimus problemų būdus. Tikimasi, kad tai paskatins Lietuvos verslo ir akademinę bendruomenę aktyviau domėtis šia sritimi.

\section{Klasterių veiklos vystymo Lietuvoje problemos}

Pasauliniu mastu klasterio problemos aptariamos daugelyje mokslinès literatūros šaltinių (Andriani et al., 2005, Bekar, Lipsey, 2001, Cruz, Teixeira, 2007, European Commission, 2003, Frerot, 2008, Roelandt et al., 2000). Konkurencingumas - gana sparčiai kintanti atskiro verslo subjekto (taip pat ir klasterio) savybè, kadangi igytos konkurencinès pozicijos laikinos, jei produktyvumo didejjimo tempai atsilieka nuo konkurentų tempų. Konkurenciją skatinančios priemonès taikomos kaip reakcija ị jau ìvykusius pokyčius rinkoje, tačiau dažnai jos būna pavèluotos ir reikalaujančios tam tikrų organizacinių pokyčių, kurių igyvendinimas klasteryje būna sudètingesnis nei atskiroje įmonèje. Kita vertus, dažnai aplinkos pokyčių tempai yra dideli, todẻl darosi sudètinga ịvertinti jų poveikị ir prognozuoti klasterio veiklos rezultatus. Todèl būtina 
ieškoti naujų būdų, kurie padètų nustatyti konkurencingumą lemiančius veiksnius, jų ¿̇vertinimo būdus, rezultatų aprobavimo galimybes (Stalgienè ir Paunksniené, 2009). Pagrindiniai palankios klasterių kūrimui terpès ir jo konkurencingumo požymiai yra:

- gerai išvystyta inovacijų infrastruktūra;

- pažangi švietimo ir mokslinių tyrimų sistema;

- pakankami rizikos kapitalo resursai;

- antreprenerystès dvasia visuomeneje;

- stipri imoné (kelios), vaidinančios proceso katalizatoriaus vaidmeni.

Visi šie veiksniai Lietuvoje nèra reikiamai išvystyti, nors verslumas yra pakankamas.

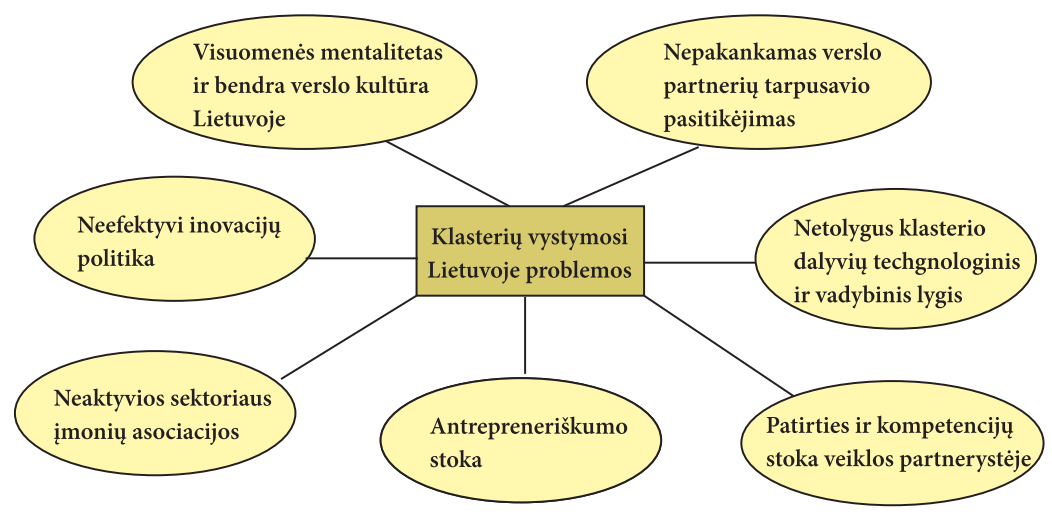

1 pav. Pagrindinès klasterių vystymosi Lietuvoje problemos (sudaryta autorių)

- Visuomenès mentalitetas ir bendra verslo kultūra Lietuvoje. Lietuvos verslo visuomenejje vis dar vyrauja polinkis sukurti vertę remiantis mažomis sąnaudomis, neigiamas požiūris ị dalijimąsi pelnu ar išaugusia verte, vengimas rizikuoti ir pernelyg ịsigalëjęs polinkis tikètis valstybės ar ES fondų finansinès paramos, nors mokestinès sistemos nèra pagrindo laikyti nepalankia inovacijoms. Taip pat atkreiptinas dèmesys, jog patiems verslo subjektams trūksta iniciatyvos bendradarbiauti su mokslo institutais ir universitetais siekiant sukurti pagrindą inovacijoms - dažniausiai apsiribojama tik tais projektais, kurie yra finansuojami trečiųjų šalių. Be to, mokslo institucijų bendradarbiavimas su verslo ir pramonès įmonemis išlieka menki, kadangi mokslinių rezultatų diegimui versle ịprastai reikalingi nemaži laiko resursai, kurių verslo atstovai nèra linkę skirti, o vietoj to tiesiog renkasi trumpalaikius, tačiau aiškią naudą teikiančius projektus. Dèl šios priežasties Lietuvoje verslo subjektų investicijos $\mathfrak{i}$ inovacijas yra menkos, nors valstybẻ tuo tikslu skiria nemažai biudžeto lèšu. ES valstybės moksliniams tyrimams ir inovacijoms skiria šiek tiek daugiau kaip $2 \%$ BVP, tačiau Lietuvoje šio rodiklio reikšmė nesiekia 0,9 $\%$ BVP. Be to, valstybès skiriama dalis sudaro $0,66 \%$ ir ši dalis yra nuosekliai didinama, o verslo subjektai skiria tik $0,2 \%$. Šiuo atveju būtina skatinti mokslo institucijų ir verslo subjektų bendradarbiavimą, kad verslo subjektai pamatytų 
tokio investavimo naudą ir patys būtų suinteresuoti skirti didesnes investicijas MTEP. Taip pat dèl riboto intelektinio potencialo neišnaudojamos licencijavimo ir patentų pajamos, t. y. negaunama tiek pajamų, kiek kitose Europos šalyse. Tai ne tik apsunkina ir inovacijų diegimą bei klasterizacijos procesus, bet kartu kelia socialinių problemų valstybei.

- Nepakankamas verslo partnerių tarpusavio pasitikèjimas. Pasitikèjimas tarp verslo partnerių yra kritiškai svarbus bet kurios verslo partnerystės sąlyga. Pasitikejjimo kitais klasterio dalyviais stoką lemia daug priežasčių. Visų pirma privatizacija, restruktūrizacija, globalizacija ir kiti išorès pokyčiai nepriklausomybès laikotarpiu radikaliai pakeitė anksčiau buvusius ryšius, pasikeitè daugelio i̇monių vadovai. Kita vertus, lengvos ir mažai kompetencijos reikalaujančios sąlygos, pvz., gana nesudètingas ES finansinès paramos pasiekiamumas, iškreipe nemažos dalies verslininkų požiūrị ì profesionalią vadybą ir verslo sampratą apskritai. Taip pat nèra iki galo susiformavusi verslo kultūra, reikalaujanti iš partnerių griežto sutartų sąlygų laikymosi. Be to, ịprastinis požiūris ì verslo organizavimą menkai skatina įmones specializuotis, taip pat ši procesą stabdo noras išvengti priklausomybès nuo kitų verslo subjektų apsaugant savo verslo interesus. Sunkiausiai pataisoma priežastis yra faktas, kad dèl nepakankamos kompetencijos ir techninių bei kitokių galimybių stokos sunku rasti kokybišką ir patikimą verslo partnerị.

- Netolygus klasterio dalyvių technologinis ir vadybinis lygis. Nors šiuolaikiniam verslui būdingas specializacijos siekimas, tačiau kai kurios tarptautinèse rinkose esančios sẻkmingos įmonès vykdo priešingą strategiją. Tokios i̇monès igyvendino vertikalią integraciją, pagrindinę veiklą papildydamos technologiškai su jų procesu susijusiomis veiklomis, kadangi neranda tinkamo partnerio, kuris galètų užtikrinti kokybišką ir laiku prisiimtų issipareigojimų įvykdymą. Kita vertus, užsiimti tokia veikla skatina noras investuoti laisvas léšas ị kol kas ne itin konkurencingą verslo segmentą, kuriame įmonè gali panaudoti savo sukauptą patirtị, ryšius ir kompetenciją (Ūkio ministerija, 2003). Taip pat netolygus vadybinis lygis apsunkina klasterio dalyvių komunikaciją, stipresniems klasterio dalyviams mažina motyvaciją skirti pakankamai laiko bei kompetencijų plètoti savo dalyvavimą klasteryje.

Veiklos partnerystèje patirties ir kompetencijos stoka. Klasterių, kitų kooperacinių verslo partnerystès formų bei virtualių verslo sistemų valdymas kokybiškai iš esmès skiriasi nuo ịprastinès verslo įmonès vadybos. Be to, šioje vadyboje yra ryškūs ir mokslo vadybos, kuri Lietuvoje nèra aukšto lygio, elementai. Nors ir viešasis sektorius, ir verslo i̇monès turi bendradarbiavimo patirties igyvendindami ES finansuojamus projektus, tačiau tokia vadyba nèra be trūkumų. Nèra pakankamai asmenų, gebančių užtikrinti sklandų bendradarbiavimą tarp skirtingų institucijų ir kurie gebėtu suvokti bei suderinti pelno siekiančių ir ne pelno siekiančių institucijų interesus. Be to, Lietuvos klasterių veiklos istorijoje užsienio partnerių, kurie suteiktų ne finansavimo šaltinius, o kompetencijas, ịtraukimas išlieka vis dar retas reiškinys. Vis dar nèra aišku, ar pakankamas projektų, igyvendintų skatinant inovatyvią veiklą Lietuvoje panaudojant ES struktūrinių fondų lèšas, rezultatų tvarumas. 
- Taip pat nèra iš esmès pasikeitęs ir atitinkamų valdymo institucijų požiūris i inovacinių projektų igyvendinimą. Šiuo metu Lietuvos įmonése bei organizacijose yra tik labai ribotas skaičius žmonių, turinčių tokią kompetenciją.

- Antrepreneriškumo stoka. Antreprenerystẻ suprantama kaip tokia subjekto veikla, kai sąmoningai prisiimami aukšti veiklos siekiai, gebama akumuliuoti ne tik savo, bet ir kitų veiklos rezultatais suinteresuotų ịmonių ar organizacijų išteklius, siekiant užsibrèžto tikslo. Antrepreneriškumo stoka pasireiškia įmonių pastangomis kopijuoti viena kitą, menkomis pastangomis derinti skirtingus veiklos metodus, ieškoti novatoriškų sprendimų (Ūkio ministerija, 2003). Nors yra nemažai kūrybiškų, netipiškai mąstančių ir veikiančių verslininkų bei įmonių vadovų, tačiau bendras antrepreneriškumo lygis Lietuvoje vis dar nèra aukštas. Vienas iš akivaizdžių antrepreneriškumo trūkumo pavyzdžių yra verslo i̇monių veiklos uždarumas ir nenoras bendradarbiauti, pvz., vengiant sukurti sąlygas aukštųjų mokyklų praktikantams, bendradarbiauti su universitetais tobulinant studijų programas ar sprendžiant technologines verslo problemas.

- Neaktyvios sektoriaus įmonių asociacijos. Lietuvoje veikia daug šakinių, regioninių ar specializuotų asociacijų, tačiau dauguma jų nèra aktyvios ir menkai sutelkia sektoriaus įmones. Dauguma asociacijų yra nominalios, vienija tik mažąją dalị tos šakos ar specifinès kompetencijos įmonių bei organizacijų. Tačiau būtent jos galètų būti viena svarbiausių iš klasterio branduolị sudarančių institucijų. Daugeliu atvejų tokių asociacijų veikla apsiriboja lobistine veikla derinant imonių interesus valdymo institucijose, taip pat perteikiant ES dokumentų reikalavimus ar kitas naujienas. Tačiau to nepakanka siekiant, kad asociacija taptų reikšminga klasterio dalyvè, o juo labiau - svarbiausia siejančia grandimi (Ūkio ministerija, 2003). Situacija pasikeistų, jei asociacija išties taptų ne nominali, o realiai sektoriaus įmonėms atstovaujanti organizacija su savo kompetencijų centru ir gebètų generuoti idejas bei sutelkti ne tik verslo, bet ir mokslo institucijų atstovus.

- Neefektyvi inovacijų politika. Viena iš svarbiausių klasterių savybių - jų novatoriškumas ir tikslas gauti tokius rezultatus, kurių nepavyktų pasiekti mokslo institucijoms ir verslo subjektams veikiant atskirai. Pati klasterio struktūra ir jų dalyvių bendradarbiavimas lemia naujoves daugelyje veiklos sričių. Tačiau, kad kurtųsi novatoriški klasteriai, reikalinga inovacijoms palanki terpe visuomenèje. Ją galima sukurti valstybès institucijoms deramai užsiimant finansuojamų mokslo projektų sklaida ne tik internetu, bet ir plačiai panaudojant kitas žiniasklaidos priemones taip prisidedant prie bendro visuomenès švietimo. Taip pat būtinas tinkamas mokslo ir inovacijų skatinimo sistemos finansavimas, suteikiant daugiau mokestinių lengvatų verslo įmonių moksliniams tyrimams ir eksperimentinei veiklai. Taip pat stiprų postūmị lemtų biurokratinès naštos mokslo darbuotojams mažinimas ir paskata mokslo isstaigoms ir universitetams sujungti savo mokslines pajėgas palaikant neformalių mokslininkų grupių kūrimąsi. Kita vertus, ko gero, svarbiausia valstybès inovacijų politikos dalis, kuri kartu ir pati sudètingiausia, - intelektinių šalies 
resursų konsolidacija sujungiant universitetus ir mokslo institutus, taip pakeliant jų valdymo kokybę.

Galimų klasterių fasilitavimo pavyzdinių modelių taikymo Lietuvoje teisinis ir ekonominis vertinimas atliktas (Klasterių fasilitavimo pavyzdiniai modeliai, 2013). Be to, taip pat išnagrinètos klasterių veiklos atskirose srityse problemos ir galimybès (Grublienè, 2009, Lietuvos ūkio ministerija, 2003, Pelanienè et al., 2007, Vaitkevičius ir Stalgienè, 2010, Všt Turizmo plètros institutas, 2007).

\section{Klasterių veiklos rizikos struktūra}

Diegiant inovacijas dažnai susiduriama su problemomis, kurios sunkina ar stabdo inovacinių procesų eigą. Organizacijos ir jų vadovai yra labiau linkę rizikuoti tose srityse, kuriose konkrečiai žinomos galimybès ir potencialios pasekmès (Giedraitytė ir Raipa, 2012). Todèl, tobulinant klasterių rizikos valdymą, svarbu atrasti saugią erdvę, kur inovaciniai procesai bei paslaugos būtų išbandomos. Klasterių veiklos rizika gali būti apibūdinama kaip būsimų rezultatų neapibrěžtumas, nežinojimas. Kadangi inovacijų kūrimą ir komercializavimą apimanti klasterių veikla ịprastai yra ilgalaikis ir daugialypis procesas, labiausiai jis sietinas su neapibrěžtumu ateityje, išorès kapitalo imlumu ir net nežinomų rizikos rūšiu egzistavimu. Be visų kitų rizikos rūšių, kurių apibrèžimai ir vertinimo būdai išplètoti Baselio III susitarime (Bank for International Settlements, 2011) dèl bankų kapitalo pakankamumo, klasterių veikloje atsiranda papildomų specifinių rizikos rūšių, kurios yra svarbios planuojant sklandžią klasterio veiklą.

Interesų nesutapimas ir paslëpta konkurencija. Verslo interesų ịvairovė gali žlugdyti klasterių veiklą, kadangi jo dalyvių interesai ir prioritetai gali skirtis tarpusavyje. Klasterị sudarančios įmonès gali būti tarpusavyje konkuruojantys verslo subjektai, todèl tokios aplinkybès apsunkina jų bendradarbiavimą dalijantis technologinèmis žiniomis ir informacija apie rinkas bei kitus svarbius verslo procesus, kuri turètų būti išnaudota kuriant inovacijas ar kitaip plètojant klasterio veiklą. Visa tai riboja kokybišką ir pakankamą apsikeitimą informacija tarp dalies klasterị sudarančių verslo įmonių. Klasterizacija negali būti efektyvi be kokybiškos informacijos ir jos mainų. Be to, Lietuvai vis dar būdingas menkas verslininkų gebejjimas susitarti iggyvendinant ilgalaikius projektus, kai grąža pasiekiama ne trumpuoju, o ilgesniu laikotarpiu.

Technologinė rizika. Kaip ir daugeliui verslo subjektų, klasteriui, ypač komercializuojančiam inovacijas, svarbu apsaugoti savo verslą neplatinant konfidencialios informacijos apie sukurtas technologijas. Būtina tokiomis aplinkybėmis išsaugoti konfidencialumą, ir tai yra sudètinga užduotis, jei klasterị sudaro daug skirtingų subjektų su skirtingais interesais. Taip pat komercializuojant inovacijas visada išlieka rizika, kad kiti konkurentai sukurs pažangesnes technologijas, kurios suteiktų joms konkurencinị pranašumą užimant kuriamo produkto rinką. Taip pat, nepaisant egzistuojančių teisinių instrumentų apsaugant išradimus, išlieka aktualus uždavinys apsaugoti savo idejas nuo kopijavimo. Vis dèlto nèra patikimo būdo apsaugoti klasterio interesus. 
Neadekvataus išorinio finansavimo rizika. Komercializuojant inovacijas nèra iki galo aišku, kokios apimties finansavimas reikalingas. Tik laikas parodo, kokio lygio buvo prisiimta rizika bei jai adekvatus finansavimas. Dèl didelio neapibrèžtumo ir dèl potencialiai skirtingų verslo interesų išlieka sudètinga net ir rizikos kapitalo fondui skirti adekvatų finansavimą tais atvejais, kai verslo planas yra pagrịstas lūkesčiais, o ne patirtimi.

Koreliacijos rizika. Suteikdamas finansavimą klasterio projektui kreditorius ne tik rizikuoja dèl atskiros paskolos negrąžinimo, bet ir prisiima papildomą sisteminio pobūdžio riziką, atsirandančią dèl klasterio dalyvių tarpusavio sąsajos, t. y. kai kelias finansines pozicijas sieja ta pati ekonominès veiklos rūšis bei tikslas, paskolas gavusios imonès priklauso tam pačiam akcininkui arba nuo tos pačios inovacijos komercializavimo sėkmès ir pan. Dẻl to kyla poreikis diversifikuoti klasterio kredito riziką. Nustatyti priklausomybę tarp atskirų įmonių bankroto - sudètingas uždavinys (labiau ekonominis nei matematinis) dèl tam reikalingų duomenų trūkumo, juo labiau kad kelių susijusių i̇monių bankrotas vienu metu yra itin retas ịvykis (Valužis, 2008). Šiuo atveju iškyla daug kiekybinio koreliacijų vertinimo problemų ne vien dẻl duomenų trūkumo, bet ir dèl nuolat kintančių priklausomybės struktūrų bei išorinių sąlygų kaitos. Vis dèlto yra sukurta nemažai kredito rizikos modelių, suteikiančių galimybę pakankamu tikslumu įvertinti susijusių nemokumų rizikos lygị (Valužis, 2008).

\section{E. verslo klasterio veikla Lietuvoje}

Lietuvoje E. verslo klasteris buvo ịkurtas 2010 metais, tačiau pasaulyje - tai nèra pirmasis e. verslo klasteris. Ši idejja plačiai taikoma Japonijoje ir kai kuriose Azijos šalyse. E. verslo klasterị sudaro informacinių technologijų įmonių, kurios turi tikslą sukurti unifikuotą daugiafunkcinių e. paslaugų teikimo platformos prototipą, t. y. atvirų standartų e. paslaugų tiekimo sistemą, kuri leistų ì vieną kortelę integruoti vartotojo identifikavimo, mikromokejjimų, nuolaidų, dovanų, e. parašo, darbuotojo pažymèjimo funkcionalumą, taip pat naudojantis ja būtų galima nusipirkti ir kortelèje išsaugoti visuomeninio transporto bilietus bei bilietus $\mathfrak{i}$ renginius, patogiai ir greitai apmokèti už smulkius pirkinius, atsiskaityti internete už muzikos įrašus, žaidimus, skelbimus, atlikti balsavimo ir reitingavimo funkcijas. Tolesnis ateities tikslas - visas šias korteles perkelti ir ị mobilųji telefoną. Siekiant šio tikslo buvo numatyta 2,5 metų investuoti $10 \mathrm{mln}$. Lt ir įrengti specializuotas tyrimų laboratorijas bei mokymo centrą, ịsigyti modernias aukšto saugumo lygio elektroninių vartotojų kortelių sistemas su elektroninès piniginès ir e. parašo funkcijomis, licencijas e. paslaugų mokejjimo platformoms, e. paslaugų ịrangos bandymų ir sertifikavimo įrangą.

Pirmojo Lietuvoje E. verslo klasterio nariai: UAB „E-verslo klasteris“, UAB „Tapsis“, UAB „Salteka“, UAB „Baltpay“, UAB „Pardavimo automatai“, UAB „Dovela“, UAB „MBG Consulting“, UAB „Nsoft“, UAB „Viena sąskaita“, UAB „Baltic Car Equipment“, UAB „Dagos technologijos“, UAB „Ambernetas“, Kauno technologijos universitetas, UAB „Midpoint“, UAB „Skaitos kompiuterių servisas“. Ilgalaikèje perspektyvoje E. verslo klasteris siekia suburti bendrus interesus turinčių i̇monių ratą ir suformuoti klasterio mokslinių tyrimų ir technologinès plètros infrastruktūrą: įrengti 
mokslinių tyrimų bei mokymo centrus, kuriuose bus igyvendinami bendri klasterio narių MTTP projektai, kaupiamos žinios apie e. paslaugų rinkas bei technologijas, plètojama atvirų standartų e. paslaugų sistema. E. verslo klasterio steigimą lèmè tokios pagrindinès priežastys:

- informacinių technologijų kompanijų ir universiteto bendradarbiavimo patirtis bei tolesnio noro kartu plèsti verslą;

- Všt Lietuvos verslo paramos agentūra parama kūrimo ịrangai, laboratorijoms ir klasterio viešinimui.

- gauta Europos Sąjungos struktūrinių fondų finansinė parama.

- Iki šiol E. verslo klasteris sukūrè du produktus:

- mikromokejjimų sistemą „Tapsis“, skirtą administruoti mokejjimus maitinimo ìstaigose, savitarnos vietose, elektroninejje erdveje už e. turinị ir pan. Ši sistema suteikia galimybę klientams mokèti už produktus ir paslaugas tokiose vietose, kuriose žmonėms reikia turèti smulkiųjų pinigų, bet žmonės ne visada jų turi ir nèra patogu juos nešiotis, taip pat - dalyvauti lojalumo programose. Taip pat ši sistema suteikia galimybę naudotis kitomis elektroninemis paslaugomis;

- IP televizijos paslaugą, kuri suteiktų vartotojams galimybę rinktis ir mokèti tik už tą TV kanalą, kuriuo naudojasi. Be to, už mokamas paslaugas vartotojas galètų sumokèti naudodamasis „Tapsis“ sistema, distanciniu televizoriaus pulteliu.

- Ištyrus klasterio dalyvių atsiliepimus, galima išskirti tokias pagrindines E. verslo klasterio veiklos problemas:

- daugelio įmonių bendros veiklos valdymas yra sudètingas, kadangi nèra paprasta sujungti ir bendradarbiauti keletui kompanijų, kurios turi skirtingų interesų ir ịvairaus pobūdžio vidinių problemų. Taip pat sudėtinga komunikuoti ir užtikrinti sprendimų prièmimą laiku;

- didelis ir neprognozuojamas kuruojančios valstybės institucijos (Lietuvos verslo paramos agentūros) biurokratizmas;

- papildomos administracinès naštos poreikis, t. y. reikalingi du trys žmonès projektui administruoti;

- darbo pasiskirstymo. Skirtingas kompetencijų lygis ir komunikacijos stoka apsunkina efektyvų darbo paskirstymą ir lemia papildomas laiko sąnaudas;

- finansavimo trūkumo, kurị lemia neapibrèžtumas ir įmonių siekimas pelno bei palyginti menka orientacija ị ilgalaikius klasterio veiklos rezultatus.

Galima daryti išvadą, kad E. klasteriui būtina stiprinti tarpusavio komunikaciją siekiant išvengti verslo proceso neapibrèžtumų. Tuomet būtų paprasčiau paskirstyti darbus atsižvelgiant ị kiekvienos įmonès dydị, veiklą bei kompetenciją.

\section{Valstybės vaidmuo klasterių veikloje}

Pavienès Lietuvos verslo ir mokslo institucijos, veikdamos atskirai, yra pernelyg silpnos, kad pasiektų rimtesnių rezultatų inovacijų srityje ar juo labiau proverži šalies mastu. Nors lazerių sektoriaus ir biotechnologijų sektoriaus veikla Lietuvoje išsiskiria sèkmingais rezultatais, vis dèlto šalies mastu klasterizacijos rezultatai nèra pakankami. 
Be to, konstatuojama, kad, nors suvokiama inovacijų plètros svarba modernios ekonomikos plètrai, tačiau trūksta aiškios vizijos ir gebėjimų efektyviai valdyti valstybès intervencijas inovacijų srityje (VšI Viešosios politikos ir vadybos institutas, 2011). Panašu, kad valstybė, siekdama toliau skatinti inovatyvių klasterių steigimąsi, didžiausią proverži atliktų, jei skatintų universitetų jungimąsi ir sutelkdama atskiras mokslininkų pajègas. Taip pat būtina mažinti biurokratinę naštą mokslininkams, kurie savo laiką galètų skirti tiesioginiam darbui. Kaip tik klasterio lyderiaujančios institucijos vaidmuo galètų būti inovacinio projekto vadyba, o mokslo institucijos atliktų mokslinių tyrimų ir eksperimentų paslaugas. Kol kas tokia veikla iš esmès yra vangi.

Inovacinès aplinkos kūrimui didelès įtakos turi valdymo institucijų užduočių pasiskirstymas, politinių partijų požiūrio ị inovacijų kūrimo galimybes pokyčiai. Deklaruojama, kad inovacijos yra vienas iš Lietuvos ekonomikos variklių, todèl būtina sutelkti tiek viešuosius, tiek privačiuosius intelekto išteklius ir skatinti idejjas komercializuoti. Kita vertus, siekiant dar reikšmingesnio proveržio, būtina ugdyti kūrybinị mąstymą. Tai reiškia ne vien tik vakarų šalyse paplitusi polinkị išlaisvinti asmenybès protą žmogų ugdant nuo darželio, pradinès klasès, kai vaikams sudaromos sąlygos eksperimentuoti, žaisti, bet sukurti tokị mechanizmą, kurs iš esmès leistų pasinaudoti emigravusių mokslininkų potencialu, taip pat - užsienio mokslo institucijų laimèjimais.

Skirtingai nei JAV, Lietuvoje nėra išplètota valstybės užsakymų inovacijas kuriantiems klasteriams praktika, kai valstybè pateikia tam tikras idèjas, ko jai reikia, o iš to vèliau atsiranda nauji verslai, pagrịsti naujomis technologijomis, pritaikomomis ir kituose dalykuose.

Neretais atvejais yra susiformavusi tokia viešojo ir privataus sektoriaus bendradarbiavimo praktika, kad didžioji dalis vykdomo projekto rizikos atitenka viešajam sektoriui. Iš tiesų tai galima interpretuoti kaip didžiulę finansinę paramą verslo įmonèms. Kita vertus, tai gali jas paskatinti piktnaudžiauti prisiimama rizika. Viešojo ir privataus sektoriaus partnerystè ne tik suteikia galimybę perimti abipusę praktiką, sukurti ir įdiegti efektyvesnes paslaugas, bet ir kartu pasidalinti riziką (Giedraityte ir Raipa, 2012). Svarbu, kad klasterio dalyviai aiškiai apibrèžtų, pasiskirstytų riziką ir kad daugiausiai jos prisiimtų būtent ta institucija, kuri sugeba geriausiai ją kontroliuoti bei gali padidinti naudą. Taip pat svarbu, kad didžiąją dalị klasterių veiklos rizikos prisiimtų ne vien tik viešasis, bet ir privatus sektorius, o visų klasterio dalyvių pareiga būtų suformuluoti aiškią rizikos valdymo strategiją.

\section{Išvada}

Nepaisant gana sėkmingos E. klasterio veiklos, apskritai klasterių veikla kuriant inovatyvius produktus Lietuvoje vis dar nèra pasiekusi esminio kokybinio proveržio ne vien dèl šalies valdymo institucijų, koordinuojančių inovacijų plètrą, neveiklumo, bet ir dèl verslo įmonių veiklos trūkumų. Keletas iš pagrindinių vidinių priežasčių, slopinančių sẻkmingą klasterių veiklą, - pasitikejjimo tarp klasterio i̇monių stoka ir nevienodas vadybinis lygis, stipri priklausomybè nuo išorès finansinès paramos ir 
pernelyg angažuotas jos siekimas, kompetencijų trūkumas ir itin menka antreprenerystès kultūra. Inovacine veikla užsiimantiems klasteriams taip pat būdinga sudètingos struktūros rizika, kadangi ji susijusi su dideliu neapibrèžtumu ir besiskiriančiais klasteryje dalyvaujančių įmonių interesais. Taip pat tobulintinas ir valdymo instituciju vaidmuo, ypač - administracinès veiklos mokslo institucijoms, kuriančioms inovacijas, mažinimo linkme.

\section{Literatūra}

Andriani, P.; Jones, C.; Perkmann, M.; De Propris, L.; Sena, V.; Delbridge, R.; Möslein, K.; Neely, A. 2005. Challenging Clusters. The Prospects and Pitfalls of Clustering for Innovation and Economic Development. Advanced Institute of Management Research.

Bekar, C.; Lipsey, R. G. 2001. Clusters and Economic Policy. Policies for the New Economy, Montreal.

Cruz, S. C. S.; Teixeira, A. A. C. 2007. A New Look into the Evolution of Clusters Literature: A Bibliometric Exercise. FEP Working Papers, 257, p. 1-37.

Final Report Of The Expert Group On Enterprise And Networks. 2003. European Commission.

Frerot, O. 2008. Cities and Clusters in Europe, How Cities are Supporting Clusters. Agence d'Urbanisme pour le développement de l'agglomération lyonnaise, December,

Grublienè, V. 2009. Lietuvos jūrų ūkio klasteris - darnios regiono pletros instrumentas. Verslas, vadyba ir studijos. p. 66-78.

International Convergence of Capital Measurement and Capital Standards. Basel Committee on Banking Supervision, Bank for International Settlements, Basel June 2011.

Inovaciju skatinimo politikos vertinimas. 2011. Vilnius: Všt Viešosios politikos ir vadybos institutas.

Jucevičius, R. 2008. Klasterių ABC. [žiūrèta 2014-04-16] <http://www.ukmin.lt/ uploads/documents/imported/lt/veikla/ veiklos_sritys/ino/VM_bendradarbiavimas/
Klasteriai/doc/KKT_Jucevicius_Klasteriu_ ABC_200811[1].pdf>

Jucevičius, R. 2009a. Klasteriu vadovas. [žiūrèta 2014-04-16] <http://www.ukmin. lt/uploads/documents/imported/lt/veikla/ veiklos_sritys/ino/VM_bendradarbiavimas/ Klasteriai/doc/klasteriu\%20vadovas.pdf>

Jucevičius, R. 2009b. Klasterių kūrimuisi perspektyvios sritys. [žiūrèta 2014-04-16] $<$ http://www.klaster.lt/uploads/documents/ KKT_Jucevicius_Klasteriu\%20kompetencijos\%20tinklas_20090807.pdf>

Jucevičius, R.; Uus, I.; Valiukonyte, D. 2008. Organizaciju tinklai. KTU leidykla „Technologija“

Jucevičius, R.; Kiškienè, A.; Leichteris, E.; Stumbrytè, G. 2012. Klasteriu studija. Vilnius: Žinių ekonomikos forumas.

Giedraitytė, V., Raipa, A. 2012. Rizikos valdymas viešojo sektoriaus inovaciniuose procesuose. Viešoji politika ir administravimas. 11(4), 607-618.

Kamarulzaman, A.; Mariati, N. 2008. Cluster Based Policy Making: Assessing Performance and Sustaining Competitiveness. Review of Policy Research. 25(4).

Klasteriu fasilitavimo pavyzdiniai modeliai. 2013. Vilnius: Všst „Šiaurès miestelio technologijų parkas“, UAB „AAA Baltic Service company".

Kurortologijos tyrimu klasterio Druskininkuose galimybiu studija. 2007. Vilnius: Všt Turizmo plètros institutas.

Lietuvos pramones klasteriu pletros programine studija. 2003. Kaunas: Lietuvos ūkio ministerija. 
Pelanienè, N.; Stalgienè, A.; Galnaitytè, A. 2007. Žemès ūkio ir maisto pramonès subjektų struktūra. Lietuvos žemès ir maisto ūkis. Vilnius.

Porter., M. E. 1998. The competitive advantage of nations: with a new introduction. Basingstoke, London: Macmillan.

Roelandt, Th. J. A.; Gilsing, V. A.; Sinderen, J. 2000. Cluster - Based Innovation Policy: International Experiences. Erasmus University Rotterdam, Research Memorandum 0012.

Stalgiene, A. ir Paunksnienè, J. 2009. Klasterizacija - prielaida didinti Lietuvos maisto ir gèrimų pramonès konkurencingumą? $\mathrm{Va}$ - dybos mokslas ir studijos - kaimo verslu ir ju infrastruktūros plètrai. 16(1).

Stalgienè, A. Klasterių vystymosi barjerai. 2010. Management theory and studies for rural business and infrastructure development. Research papers. 5(24).

Vaitkevičius, S. ir Stalgienè, A. 2010. Klasterizacijos raiška Lietuvos grūdų sektoriuje. Management theory and studies for rural business and infrastructure development. Research papers. 22(3): 1-8.

Valužis, M. 2008. Some Generalizations of the Structural Models of Credit Risk. Doctoral dissertation. Vilnius: Vilnius University.

\title{
CLUSTER ACTIVITY IN LITHUANIA: CHALLENGES AND SEARCH FOR OPPORTUNITIES
}

\author{
Aelita Skaržauskienè \\ Mykolas Romeris University, Lithuania, aelita@mruni.eu \\ Laura Gudelyte \\ Mykolas Romeris University, Lithuania, l.gudelyte@mruni.eu \\ Asta Lančinskienè \\ Mykolas Romeris University, Lithuania, asta.lancinskiene@gmail.com
}

\section{Summary}

Purpose - to analyse and summarise the problems of innovative business cluster performance in Lithuania and provide suggestions on how to improve the situation and to identify the main sources of their activity risk

Methodology - general review of scientific literature that analyses the efficiency of clusters and factors that have a negative impact on their business; a case study.

Results - problems of cluster performance in Lithuania analysed and the main types of risk of cluster activity identified.

Research limitations - study limitations arise due to the lack of quantitative data and the confidentiality of insider information. For this reason, it is difficult to create adequate models of efficiency assessment.

Practical implications - the development of innovation industry in the public environment and the academic environment is based on the one-sided point of view as a progress indicator in Lithuania. However, there is too little debate on whether 
the cluster is a truly optimal form to create the conditions for the development of business innovations. Despite the fact that innovations are the main subject of venture capital funds financing, the risks related to innovation and clustering have also been insufficiently analysed. This article seeks to identify the risk characteristics and structure inherent in business clusters.

Value - the main problems of cluster activity in Lithuania, the main types of cluster activity risk and the problems of its assessment are identified.

Keywords: cluster, clustering, risk structure.

Research type: literature review, general review. 